\title{
THE STOMATOPOD CRUSTACEA COLLECTED BY THE MARIEL KING MEMORIAL EXPEDITION IN MALUKU WATERS IN 1970.
}

by

\author{
M. KASIM MOOSA *) \\ INTRODUCTION.
}

The present material was collected by the Mariel King Memorial Expedition in Maluku waters, Indonesia, during May and June 1970. The author participated as the member of the Indonesian Institute of Sciences. Although the stomatopod collected was not very great in number of the species, but consist 3 new species, one new sub-species and some rare forms. The collection is deposited in the Institute of Marine Research, Jakarta.

I would like to express my gratefulness to Dr. R.B. Manning for his help in literatures; to Dr. R. Serene for encouraging me to prepare this paper as well as his help in literatures and to Mr. Kasijan Romimohtarto for his advices.

\section{METHODS.}

Synonymies in this paper are restricted to the works, of Kemp (1913), Hansen (1926), Holthuis (1941) and Manning (1963, 1967, 1967a, 1967b, 1968, 1968a, 1969a, 1971 and 1971a). Measurements are given in millimeters (mm.) and limited up to $0.02 \mathrm{~mm}$., measurements are made by using Mitutoyo calyper. Total length (T1.) is measured from the tip of the rostrum to the submedian teeth of telson along midline; carapace length $(\mathrm{Cl}$.) is also measured along midline (rostrum excluded). The count of teeth of the raptorial dactylus always include the terminal tooth. Distribution is restricted for Maluku waters and the bordering shores only.

The present material consists the following species:

1. Chorisquilla brooksii (De Man, 1887).

2. Coronidopsis serenei new species.

3. Gonodactylus chiragra (Fabricius, 1781).

4. Gonodactylus falcatus (Forskal, 1775).

* Assistant biologist, Institute of Marine Research Jakarta. 
5. Gonodactylus segregatus Lanchester, 1903.

6. Gonodactylus smithii Pocock, 1893.

7. Haptosquilla glyptocerca (Wood-Mason, 1875).

8. Haptosquilla nefanda (Kemp, 1911).

9. Haptosquilla pulchella (Miers, 1880).

10. Haptosquilla stoliura (Miiller, 1886).

11. Haptosquilla tuberosa (Pocock, 1893).

12. Odontodactylus brevirostris Miers, 1884.

13. Odontodactylus cultrifer (White, 1850).

14. Odontodactylus scyllarus (Linne, 1758).

15. Pseudosquilla ciliata (Fabricius, 1787).

16. Acanthosquilla derijardi Manning, 1969.

17. Acanthosquilla multifasciata (Wood-Mason, 1895).

18. Acanthosquilla wilsoni new species

19. Anchisquilla fasciata (De Haan, 1844).

20. Carinosquilla multicarinata (White, 1847).

21. Clorida chlorida (Brooks, 1886).

22. Clorida malaccensis var. moluccensis new sub species.

23. Clorida miersi Manning, 1968.

24. Clorida seversi new species

25. Oratosquilla gonypetes (Kemp, 1911).

26. Oratosquilla quadraticauda (Fukuda, 1910).

Family GONODACTYLIDAE Giesbrecht, 1910

Genus Chorisquilla Manning, 1970

Chorisquilla brooksii (De Man, 1887)

Protosquilla brooksii De Man, 1887, p. 579, pi. 22a, fig. 8. - Fukuda, 1910, p. , 140, pl. iv, figs. 1, 1a, - Manning and Serene, 1968, p. 114 (listed).

Gonodactylus brooksii Kemp, 1913, pp. 189-190. — Holthuis, 1941, pp. 290-292. - Tweedie, 1949, p. 41.

Chorisquilla brooksii Manning, 1969, p. 159 (in key).

Material. - 1 त 27.96 mm.; south end of Kajoa Island, Halmahera, $00^{\circ} 05^{\prime}$ S., $127^{\circ} 27^{\prime}$ E.; coarse sand cay with jnarginal corals; Sta. KL. I, $21 / 5 / 1970$; cat. no. S. 683.

Previous Maluku record. - This species has been recorded from Tidore and from Wotap, Tanimbar (Holthuis, 1941) and Piru Bay (Anonymous, 1972). 
Genus Coronidopsis Hansen, 1926

Coronidopsis serenei new species

(fig. la, b, c, d, e)

Material. - Holotype: 1 त $38.80 \mathrm{~mm}$.; off Elat Bay, west of Nuhu Tjut Island, Kai, 05 $-40^{\prime}$ S., 132 $139^{\prime} \mathrm{E}$.; dredged, 38 fms.; mud and shells; Sta. KN. II, 13/6/1970; cat. no. S. 647.

Description. - Cornea strongly bilobed, set obliquely on stalk, outer margin of eyes longer than inner; eyes not extending to the end of first segment of the antennular peduncle; ophthalmic somite and bases of eyes are covered by rostral plate. Antennular peduncle slightly shorter than carapace (rostrum excluded). Rostral plate consists of two lobes, each lobe with a sharp apical .spine which reaches the cornea; the two lobes are separated by a wide excavation. Carapace smooth, narrowed anteriorly, without spine or carinae, except for a short marginal carina on posterior margin of each lateral plate; cervical groove faintly seen outside gastric grooves and absent between them. Raptorial dactylus armed with four teeth; outer margin, with a basal notch; propodus fully pectinate; carpus armed with a sharp tooth and an acute anterior edge on dorsal ridge; merus without inferodistal spine. Mandibular palp and five epipods present. The exposed thoracic somites without dorsal carinae; fifth ,somite with inconspicuous lateral process; lateral process of sixth and seventh somites rounded posteriorly, not bilobed. Abdomen smooth, flattened; dorsal carinae present on the last two abdominal somites only; marginal carina of the fourth somite ends in spine; on the fifth somite, the lateral carina ends in spine, marginal blunt; on the sixth the submedian, lateral and marginal end in spine while the intermediate ends in 2-3 spines, a spine present between intermediate and lateral carinae; sixth somite with two ventrolateral processes in 7 front of articulation of each uropod, outer process spinous and curved backward, inner process acute; ventral surface of sixth somite smooth on posterior margin. Telson broader than long, with a median marginal tooth and two pairs of marginal teeth on either sides of the median tooth; two broad intermediate and one broad lateral denticle present, submedian denticle absent; dorsal surface ornamented with three pairs of carinae on either side of median carina which terminates in spine, accessory median carina with four or five spines, submedian carina which is Tshaped has spine on its hands; dorsal surface ornamented with spines and spinules in somewhat symmetrical pattern; median marginal tooth with five spinules on its dorsal surface; ventral surface of telson covered with spines in symmetrical pattern; spines are arranged in three rows on either side of postanal area, postanal keel absent. Uropod with 7-8 movable spines on its outer margin of penultimate segment of outer branch and an outwardly curved fixed spine present on its tip; inner spine of basal prolongation of uropod longer than outer and armed with 5-6 spines on its inner margin. 

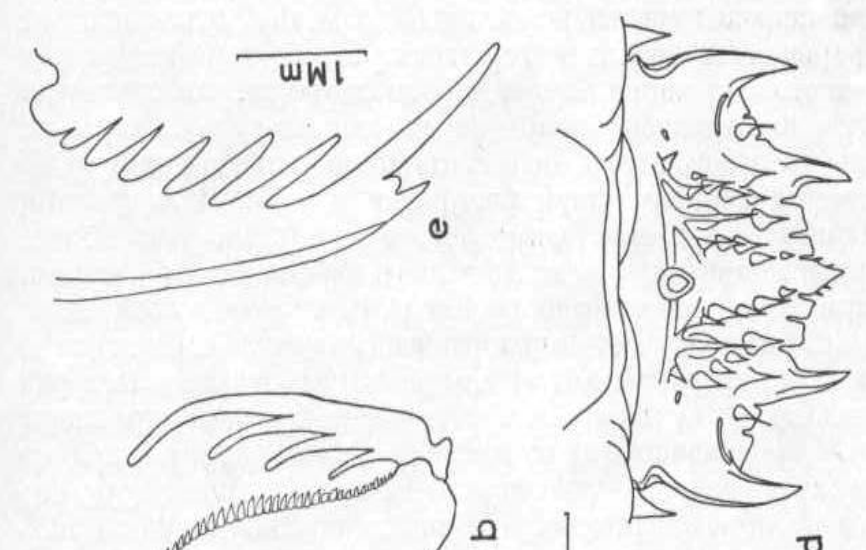

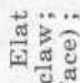

낭. 플

हैं

घ

क००

品

संᄋ
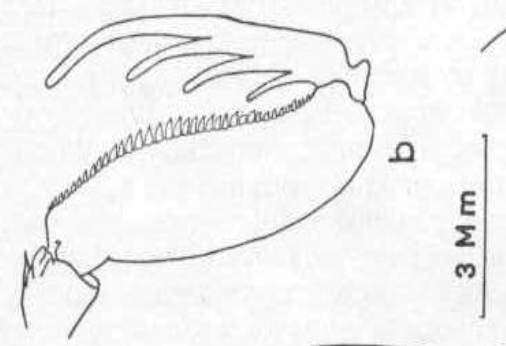

$\tau$

मैं ช

ฝิ응

造密

둥

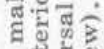

मี สี कु

पैं है न

की क्ष क्ष

$32 \pm$

율 क्ष

氝

कृ

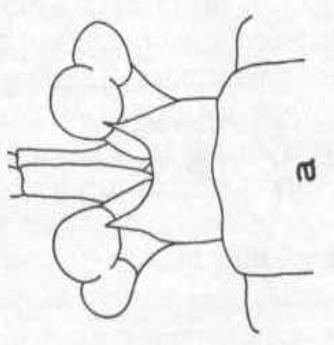

क킁ํㅇ

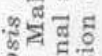

के की है

है कु क

엉

-

네

bi 20 
Other measurements, - Cl. $7.50 \mathrm{~mm}$.; cornea width $1.88 \mathrm{~mm}$.; rostral plate: length $2.38 \mathrm{~mm}$., width $2.20 \mathrm{~mm}$; t telson: length $4.32 \mathrm{~mm}$.; width $7.10 \mathrm{~mm}$.

Colour, - . The general coloration of the preserved (in alcohol) specimen is whitish. Brownish-black pigment occurs on posterior margin of carapace, on last three thoracic and first five abdominal somites, in scatterring form. Less marked pigmentation can be seen on anterior part ,of (carapace, and on distal part of merus of the raptorial claw.

Discussion, - The present specimen clearly belongs to Coronidopsis Hansen. The genus consists of two species, i.e. Coronidopsis bicuspws Hansen (Hansen, 1926) and a new species from the pulf of Tonkin (under description) which differs from the Maluku specimen according to Dr. Blumstein (personal letter). The present species can be separated from $C$. bicuspis by: 1). the presence of a median marginal tooth on the telson instead of two .movable median spines, 2). the ornamentation on the dorsal and ventral surfaces of telson which is clearly different from $C$. bicuspis as figured by Hansen (1926, pi. i, fig. 7d, e).

$C$. bicuspis and $C$, serenei is represented by a single specimen. Etimology. - The name serenei is dedicated to Dr. Raoul Serene, a well known carcinologist.

Type. - The holotype is deposited in the Institute of Marine Research, Jakarta.

Type locality. - off Elat Bay, Kai Islands, Indonesia.

Previous Maluku record. - Known only from the type locality.

Genus Gonodactylus Berthold, 1827.

Gonodactylus chiragra (Fabricius, 1781).

Gonodactylus chiragra Brooks, 1886, pp. 56-58, pi. xv, fig. 4. Kemp, 1913, pp. 155-162, pl. ix, fig. 107. - 1915, pp. 180-182. - Sunier, 1918, pp. 13-14. - Hansen, 1926, pp. 24-26. - Holthuis, 1941, pp. 277281. - Tweedie, 1934, p. 41. - 1950, pp. 139-140.

Material. - 1 त $81.66 \mathrm{~mm}$; north side of Teluk Dodinga, Halmahera, $00^{\circ} 51^{\prime}$ S., $127^{\circ} 35^{\prime} \mathrm{E}$.; top of bank coral rubble with a few small mangroves; Sta. HD. II, 20/5/1970; cat. no. S. 646. - 2 के 25.16-28.72 mm.; 5 o 0 16.28-63.74 mm.; south end of Kajoa Island, Halmahera, $00^{\circ} 05^{\prime}$ S., $127^{\circ} 27^{\prime} \mathrm{E}$; coarse sand cay with marginal coral; Sta. KL. I, 21/5/1970; cat. no. S. 647-680. - 1 o $41.44 \mathrm{~mm}$.; south end of Laluin Island, southwest of Kajoa Island, Halmahera, $00^{\circ} 05^{\prime}$ S., $127^{\circ} 26^{\prime}$ E.: marginal coral reef; Sta. KL. II, 22/5/1970; cat. no. S. 673. - 4 ๙ $38.52 \mathrm{~mm}$., 3 ㅇ 9 27.48-45.52 mm.; west side of Namwaan Island, Northwest of Jamdena, Tanimbar, $07^{\circ} 07^{\prime}$ S., $131^{\circ}$ 26'E.; coral reef; Sta. TJ. II, 23/6/1970; cat. no. S. 690-696. — 28 A? 17.84-87.22 mm., 33 o o 17.84$80,88 \mathrm{~mm}$.; north side of Labuan Olendir, Selaru Island, Tanimbar $08^{\circ}$ 07 S., 130' 59'E.; coral boulder; Sta. TS. IV, 26/6/1970; cat. no. S. 756-

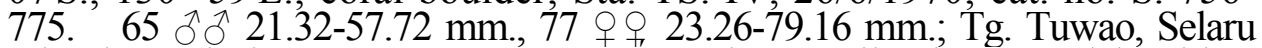
Island, Tanimbar, $08^{\circ} 11^{\prime} \mathrm{S}$., $130^{\circ} 49 \mathrm{E}$.; shore collection; coral boulder; Sta. TS. VI, 26/6/1970; cat. no. S. 776-795. 
Previous Maluku record. - This species is widely distributed and has been collected from various localities around Maluku (Sunier, 1918; Hansen, 1926; Holthuis, 1941).

\section{Gonodactylus falcatus (Forskal, 1775).}

Gonodactylus glabrous Brooks, 1886, pp. 62-64, pi. xiv, fig. 5, pi. xv, figs. 7, 9. Kemp, 1913, pp. 167-169, pl. ix, fig. 113. - Hansen, 1926, pp. 29-30. - Chopra, 1934, pp. 40-41.

Gonodactylus falcatus Holthuis, 1941, pp. 282-288, fig. 9a. - Tweedie, 1949, p. 40. - 1950, p. 140. - Manning and Serene, 1968, p. 114 (listed).

Material. - 1 O $36.20 \mathrm{~mm}$.; south end of Laluin Island, southwest of Kajoa Island, Halmahera, $00^{\circ} 05^{\prime}$ S., $127^{\circ} 26^{\prime}$ E.; marginal coral reef; Sta. KL. II, 22/5/1970; cat. no. S. 657. - 1 § (juv.), 1 + $43.88 \mathrm{~mm}$; 3-4 mi. west of Tg. Lelar, Trangan Island, Aru, $06^{\circ} 46^{\prime} \mathrm{S} ., 133^{\circ} 58^{\prime} \mathrm{E}$; dredged, 6-8 fms.; sand and rubble; Sta. A. III/5-6, 21/6/1970; cat. no. S. 648-649.

Previous Maluku record. - This species has been collected from various localities around Maluku (Hansen, 1926; Holthuis, 1941).

\section{Gonodactylus segregatus Lanchester, 1903.}

Gonodactylus segregatus Lanchester, 1903, p. 448, pi. 23, figs. 6, 7 , 7a. - Manning, 1968, pp. 51-53, fig. 16. - Manning and Serene, 1968, p. 114 (listed). - Manning, 1971 a, p. 80 (in key).

Material - 1 त 26.94 mm., 3 o 9 25.32-34.76 mm.; off Tg. Tutuhuhur, Piru Bay, Ceram, 03ำ'S., $128^{\circ} 08^{\prime}$ E.; dredged, 20-24 fms.; coral, sponge and rubble; Sta. CP. 1/7, 1/6/1970; cat. no. S. 642-645. 2 ठิ त̂ 13.90-16.16 mm., 4 5? 14.38-21.36 mm.; off Tg. Tutuhuhur, Piru Bay, Ceram, $03^{\circ} 15^{\prime} \mathrm{S} ., 128^{\circ} 28^{\prime} \mathrm{E}$.; dredged; $14-26 \mathrm{fms}$.; coarse sand, lithothamnion and rubble; Sta. CP. 1/8-14, 2/6/1970; cat. no. S. 750-755. 1 त 15.96., 5 우 17.48-20.60 mm.; off Tg. Tutuhuhur, Piru Bay, Ceram, $03^{\circ} 15^{\prime} \mathrm{S} ., 128^{\circ} 08^{\prime} \mathrm{E} . ;$ dredged, $30 \mathrm{fms} .:$ grey sand, fine shelly grit; Sta. CP. 1/15, 2/6/1970; cat. no. S. 651-656. - 3 o 9 9.28-20.58 mm.; north of $\mathrm{Du}$ Rowa Island, north of Nuhu Rowa, Kai, $05^{\circ} 32^{\prime} \mathrm{S} ., 132^{\circ} 41$ 'E.; dredged, 18-20 fms.; lithothamnion, rubble and sand; Sta. KR. VI/2, 10/6/1970; cat. no. S. 747-749. — 4 ơ o $^{1}$ 10.78-16.46 mm.; 5 우 9.46-17.68 $\mathrm{mm}$.; north of Du Rowa Island, north of Nuhu Rowa, Kai, 05³2'S., $132^{\circ} 41^{\prime} \mathrm{E}$.; dredged, 15-20 fms.; sand and rubble; Sta. KR VI/3-10, 11/6/1970; cat. no. S. 664-672. - 1 ㅇ $17.48 \mathrm{~mm}$.; off west coast of Wasir

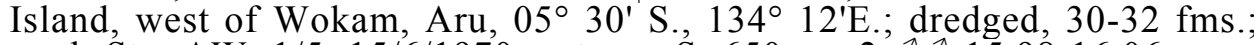
mud; Sta. AW. 1/5, 15/6/1970; cat. no. S. 650. - 2 ते $15.98-16.06 \mathrm{~mm}$., 4 우 ㅇ 14.94-19.08 mm.; approx. $8 \mathrm{mi}$. south-west of Tg. Ratoe, Maikoor, Aru, $06^{\circ} 07^{\prime}$ S., $133^{\circ} 57^{\prime}$ E.; dredged, 14 fms.; lithothamnion nodules; Sta. AM. $11 / 15,18 / 6 / 1970$; cat. no. S. 658-663.

Remarks. - The specimens agree with Gonodactylus segregatus as described by Lanchester (1903) and Manning (1968a). They also have some resemblances with Gonodactylus spinulosus Schmitt. Comparing 
the specimens with the drawing of Manning: (1966) for spinulosus and Manning (1968a) for segregatus, the resemblances seem to be closer to spinulosus, a species from Atlantic. The specimens differ from spinulosus by: 1). the absence of spine on the carina of the submedian tooth of telson, 2). carina of the submedian tooth diverges anteriorly, 3 ). the absence of the anchor behind the median carina. The resemblances to spinulosus are possibly superficial.

Previous Maluku record. The species was found only from Central and Western Indian Ocean from Comoro Islands, Madagascar, and from several localities in Maldives Islands (Lanchester, 1903). The presence of this species in Maluku shows its eastern distribution and is a new record for the area.

\section{Gonodactylus smithii Pocock, 1893.}

Gonodactylus smithii Pocock, 1893, pp. 475-476, pi. xx B, fig. 1. Serene, 1954, pp. 6-7, 76-77, pi. viii, figs. 1-4. - Manning, 1966, pp. 112113. - Manning and Serene, 1968, p. 114 (listed). - Tirmizi and Manning, 1968, pp. 23-25, fig. 8 .

Gonodactylus chiragra var. smithii Borradaile, 1898, p. 34, pi. v, fig.

2. Nobili, 1906, pp. 329-330.

Gonodactylus acutirostris Kemp, 1913, pp. 163-164.

Gonodactylus chiragra var. acutirostris De Man, 1898, p. 695, pl. xxxviii, fig. 77b, c. - Lanchester, 1903, p. 454. - Borradaile, 1907, p. 210. - Gravier, 1937, pp. 204-205, fig. 20.

Material - 2 के 36.78-45.72 mm., 8 SS 18.12-45.52 mm.; south end of Kajoa Island, Halmahera, $00^{\circ} 05^{\prime}$ S., $127^{\circ} 27^{\prime}$ E.; coarse sand cay with marginal coral; Sta. KL. I, 21/5/1970; cat. no. S. 697-706.

Previous Maluku record. - Pocock (1893) recorded this species from Arafura Sea without definite position. The present record is the first record for the area.

Genus Haptosquilla Manning, 1969

Haptosquilla glyptocerca (Wood-Mason, 1875).

Gonodactylus glyptocercus Wood-Mason, 1875, p. 32. - Kemp, 1913, pp. 186-187. - Hansen, 1926, p. 36. - Holthuis, 1941, pp. 289-290. Tiwari and Biswas, 1951, p. 362. - Stephenson, 1953, pp. 47-48. Serene, 1954, pp. 6, 51-53, figs. 4, 11d, e.

ProtosquiUa cerebralis Brooks, 1886, pp. 72-75, pi. xiv, figs. 2, 3, pi. xvi, figs. 2, 3. - De Man, 1887, p. 575. - Borradaile, 1898, p. 3, pi. v, fig. 6a. - Fukuda, 1910, p. 140.

ProtosquiUa glyptocerca Manning and Serene, 1968, p. 114 (listed). Haptosquilla glyptocercus Manning, 1969a, p. 161 (in key). 
Material. - 1 \& $17.54 \mathrm{~mm}$; south end of Kajoa Island, Halmahera, $00^{\circ} 05^{\prime}$ S., $127^{\circ} 27^{\prime}$ E.; coarse sand cay with marginal corals; Sta. KL. I,

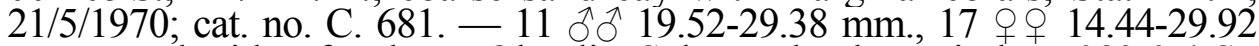
$\mathrm{mm}$; ; north side of Labuan Olendir, Selaru Island, Tanimbar, $08^{\circ} 07^{\prime} \mathrm{S}$, $130^{\circ} 59^{\prime}$ E. ; coral boulder; Sta. TS. IV, 26/6/1970; cat. no. S. 727-746. 15 đo 18.82-27.44 mm., 73 o 0 15.44-32.66 mm.; Tg. Tuwao, Selaru Island, Tanimbar, $08^{\circ} 11$ 'S., $130^{\circ} 49^{\prime}$ E.; coral boulder; ;Sta. TS. VI, 27/6/1970; cat. no. S. 707-726.

Previous Maluku record. - This species has been recorded from Ternate (De Man, 1887), Siau Island and Salibabu Island (Hansen, 1926) Banda (Holthuis, 1941), Piru Bay (Anonymous, 1972).

\section{Haptosquilla nefanda (Kemp, 1911)}

Gonodactylus (Protosquilla) nefandus Kemp, 1911, pp. 93-94.

Gonodactylus nefandus Kemp, 1913, pp. 179-180, pi. X, figs. 119-120. - Kemp and Chopra, 1921, p. 311. - Hansen, 1926, p. 53. - Chopra, J934, pp. 41-42.

Protosquilla nefanda Manning, and Serene, 1968, p. 115 (listed).

Haptosquilla nefanda Manning, 1969a, p. 162 (in key).

Material. - 3 o o 21.36-26.10 mm.; off Tg. Tutuhuhur, Piru Bay, Ceram, 03 ${ }^{\circ} 15^{\prime}$ S., $128^{\circ} 80^{\prime}$ E.; dredged, 14-26 fms.; coarse sand lithothamnion and rubble; Sta. CP. 1/8-14, 2/6/1970; cat. no. S. 822-824. 1 त 20.62 mm., 4 o $017.74-20.84$ mm.; north of Du Rowa Island, north of Nuhu Rowa, Kai, 05 $32^{\prime}$ S., $132^{\circ} 41^{\prime}$ E.; dredged 15-20 fms.; sand and rubble; Sta. KR. VI/3-10, 11/6/1970; cat. no. S. 796-800.-3 o 9 10.52$12.58 \mathrm{~mm}$.; between Du Rowa Island and Kai Dullah Island, Kai. $05^{\circ} 32^{\prime} \mathrm{S}$., $132^{\circ} 46^{\prime}$ E.; dredged, 18-20 fms.; muddy sand and sponge; Sta. KR. VII/ 1-8, 11/6/1970; cat. no. S. 817-819. - 1 त $22.66 \mathrm{~mm}$., 2 o o 22.78-28.38 mm; off west coast of Wasir Island, Aru, $05^{\circ} 30^{\prime} \mathrm{S} ., 134^{\circ} 12^{\prime} \mathrm{E}$.; dredged, 22$40 \mathrm{fms}$.; sand and shell rubble; Sta. AW. 1/7-10, 15/6/1970; cat. no. S. 813-815.

Remarks. - All the specimens agree in most characters with Kemp's descriptions (1911, 1913). Among themselves there are slight differences which possibly due to immaturity. In his descriptions and figure (Kemp, 1911; 1913, fig. 120) Kemp did not mention the presence of a spinule on posterior end of the three bosses on dorsal surface of telson. This spinule always present in all the Maluku specimens with variable size. All the specimens have similar pattern of pigmentation on the exposed thoracic and abdominal somites except on the small specimens on which this pigmentation in less marked. The main differences between them are: 1). the form of the three bosses on the dorsal surface of telson. All specimens have lateral bosses extending to middle of the telson and slightly beyond; each boss bears a spinule on its posterior margin which is well developed in some and not so in the others, this is not due to sizes of the specimens. The form of the bosses also variable. In 2 specimens (Tl. 10.74 and $26.84 \mathrm{~mm}$.) the bosses are not swollen as in the other specimens and this is not due to size or sex; 2 ). the form of the cornea. In the large specimens (Tl. 27.26 and $28.38 \mathrm{~mm}$.) the 
cornea is globular, in the small specimens (Tl. 10.74 and $21.36 \mathrm{~mm}$.) the cornea is subglobular and in the rest the cornea has transition form.

Previous Maluku record. - This species has a wide distribution in eastern Indonesian waters. From Maluku itself is was recorded only from Banda (Hansen, 1926).

\section{Haptosquilla pulchella (Miers, 1880)}

Gonodactylus trispinosus var. pulchellus Miers, 1880, p. 122, pi. iii, fig. 10. - Nobili, 1906, p. 326.

Protosquilla trispinosa var. pulchella Tattersall, 1906, p. 173. - De Man, 1902, p. 920.

Protosquilla pulchella Borradaile, 1907, p. 30. - Manning, 1968a, pp. 54-55. - Manning and Serene, 1968, p. 115 (listed). - Tirmizi and Manning, 1968, pp. 17-18, fig. 5.

Gonodactylus pulchellus Kemp, 1913, pp. 177-179, pi. x, figs. 117, 118. - Kemp and Chopra, 1921, p. 41. - Hansen, 1926, p. 33. - Hale, 1929 , p. 34. - Gravier, 1933, pp. 207-208. - Chopra, 1934, p. 41. Holthuis, 1941, p. 288, fig. 9b. - Tweedie, 1949, p. 40. - Stephenson, 1962, p. 35. - Ingle, 1963 , p. 30, figs. 29, 30.

Haptosquilla pulchella Manning, 1969a, p. 162, fig. 7a ,b. (in key).

Material. - 1 ㅇ $30.22 \mathrm{~mm}$.; southwest of Tg. Ngabordamloe, south of Trangan Island, Aru, 06 $58^{\prime}$ S., $134^{\circ} 05^{\prime}$ E.; dredged, 14-16 fms.; sand and shell rubble; Sta. AN. 1/2, 20/6/1970; cat. no. S. 641. - 4 ふ઼ 21.84$38.18 \mathrm{~mm} ., 1$ o $42.26 \mathrm{~mm}$.; approx. 3-4 mi. west of Tg. Lelar, Trangan Island, Aru $06^{\circ} 46^{\prime} \mathrm{S} ., 133^{\circ} 58^{\prime}$ E.; dredged, 6-8 fms.; sand and rubble; Sta. A. III/5-6, 21/6/1970; cat. no. S. 825-829.

Previous Maluku record. - The species has been recorded from Ternate (De Man, 1902), Amboina (Holthuis, 1941) and Tual, Kai (Hansen, 1926).

\section{Haptosquilla stoliura (Muller, 1886)}

Protosquilla stoliura Muller, 1886, p. 477, pl. v, fig. 2. - De Man, 1887, p. 576. - Zehntner, 1894, p. 213. - Schenkel, 1902, p. 582. Manning and Serene, 1968, p. 115 (listed).

Gonodactylus stoliurus Ortmann, 1894, p. 61. - Kemp, 1913, pp. 184-185. - Holthuis, 1941, p. 289. - Stephenson, 1962, p. 35.

Haptosquilla stoliurus Manning, 1969a, p. 161 (in key).

Material. - 1 त $45.02 \mathrm{~mm}$., 2 오 38.52-47.66 mm.; north side of Labuan Olendir, Selaru Island, Aru, 08 $07^{\prime}$ S., $130^{\circ}$ 59'E.; coral boulder; Sta. TS. IV, 26/6/1970; cat. no. S. 837-839.

Previous Maluku record. - The type was collected from Amboina. In Maluku it was known only from Ambon (Ortmann, 1894; Zehntner, 1894; De Man, 1887) and Piru Bay (Anonymous), 1972. Holthuis (1941). mentioned from Maluku without definite position. 


\section{Haptosquilla tuberosa (Pocock, 1893)}

Gonodactylus tuberosus Pocock, 1893, pp. 476-477, pi. xx, fig. 2. Kemp, 1913, pp. 181-182. - Serene, 1954, p. 6.

Protosquilla tuberosa Manning and Serene, 1968, p. 115 (listed).

Haptosquilla tuberosa Manning, 1969a, p. 162 (in key).

Material - 1 ㅇ $25.88 \mathrm{~mm}$; off Tg. Tutuhuhur, Piru Bay, Ceram, $03^{\circ} 15^{\prime}$ S., $128^{\circ} 08^{\prime}$ E.; dredged, 23-37 fms.; coarse foraminiferal and shell sand; Sta. CP. 1/4, 1/6/1970; cat. no. S. 832. - 2 9 $916.02-24.30 \mathrm{~mm}$; off Tg. Tutuhuhur, Piru Bay, Ceram, 03 ${ }^{\circ} 15^{\prime}$ S., $128^{\circ} 08^{\prime} E$.; dredged, 14$26 \mathrm{fms}$; coarse sand, lithothamnion and rubble; Sta. CP. 1/8-14, 2/6/ 1970; cat. no. S. 802-803. - 2 우 23.18-24.46 mm.; off Tg. Tutuhuhur, Piru Bay, Ceram, 03 $15^{\prime}$ S., $128^{\circ} 08^{\prime}$ E.; dredged, $30 \mathrm{fms}$.; grey sand, fine shelly grit, Sta. CP. 1/15, 2/6/1970, cat. no. S. 820-821. -H 35.42 $\mathrm{mm}$., approx. $8 \mathrm{mi}$. southwest of Tg. Ratoe, Maikoor, Aru, $06^{\circ} 07^{\prime} \mathrm{S} ., 133^{\circ}$ 57'E.; dredged, 25 fms.; sand and rubble; Sta. AM. II/4-5, 18/6/1970, cat. no. S. 801 .

Remarks. - The present specimens agree with the description of Pocock (1893) and Kemp (1913) in most characters. Kemp (1913) in his key separated Haptosquilla tuberosa (as Gonodactylus tuberosus) and Haptosquilla trispinosa (as Gonodactylus trispinosus) from Haptosquila pulchella (as Gonodactylus pulchellus) and Haptosquilla nefanda (as Gonodactylus nefandus) by the presence of corrugation on the fifth abdominal somite of the first two species. In their descriptions, neither Kemp nor Pocock mentioned this character. In Maluku specimens this character is clear on larger specimens (T1. 25.88 and $35.42 \mathrm{~mm}$.) and on the smaller specimens can be seen only between the submedian and marginal portion. Bosses of the sixth abdominal somite are covered with setae; submedian bosses rounded, intermediate ovate. Bosses on the dorsal surface of telson are also covered with setae: central boss rounded, lateral bosses extending beyond middle of the telson and slightly ovate. In the smallest specimen (T1. $14.90 \mathrm{~mm}$.) the median fissure of telson is relatively wider.

Previous Maluku record. - None. The species has been recorded from Macclesfield Bank, South China Sea and Vietnam. The presence of this species in Maluku shows its eastern distribution and is a new record for the area.

\section{Genus Odontodactylus Bigelow, 1893}

Odontodactylus brevirostris (Miers, 1884)

Restricted synonymy. - Odontodactylus brevirostris Manning, 1967a, pp. 22-29, figs. $6,7,8$.

Material. - 2 우 14.98-20.04 mm.; off Tg. Tutuhuhur, Piru Bay, Ceram, $03^{\circ} 15^{\prime} \mathrm{S} ., 128^{\circ} 08^{\prime} \mathrm{E}$.; dredged, 14-26 fms.; coarse sand, lithothamnion and rubble; Sta. CP. 1/8-14, 2/6/1970; cat. no. S. 830-831. 
Previous Maluku record. - This species has been recorded from Halmahera and Banda (Hansen, 1926 as Odontodactylus hansenii).

Odontodactylus cultrifer (White, 1850)

Resticted synonymy. - Odontodactylus cultrifer Manning, 1967a, pp. 18-22, fig. 5.

Material - 1 त $61.82 \mathrm{~mm}$.; west of Babi Island, Wokam, Aru, 05 54'S., 134 04'E.; dredged, 40-42 fms.; mud; Sta. AW. V/3, 17/6/1970; cat. no. S. 804.

Previous Maluku record. - The species has been recorded from the eastern part of Maluku off Frederick Hendrik Island (Dolak Island), West Irian (Manning, 1967a).

\section{Odontodactylus scyllarus (Linnaeus, 1767)}

Restricted synonymy. - Odontodactylus scyllarus Manning, 1967a, pp. 10-15, fig. 3 .

Material. - 1 त $122.64 \mathrm{~mm}$.; coast of a small island off Kampong Tajandu, Tajandu Island, Kai; rock flat; Sta. KT. IV, 9/6/1970; cat. no. S. 812.

Remarks. - Agrees with Manning's description with a slight modification: 1). rostal plate covered ocular scales; apex of rostrum sharp, curves downward, 2). posterolateral spine present on fourth and fifth abdominal somites.

Previous Maluku record. - This species has been recorded from Banda, Ambon, Elat (Sunier, 1918; Hansen, 1926; Holthuis, 1941).

Genus Pseudosquilla Dana, 1852

Pseudosquilla ciliata (Fabricius, 1787)

Pseudosquilla ciliata Kemp, 1913, pp. 96-100. - Sunier, 1918, p. 11. - Hansen, 1926, pp. 17-18. - Holthuis, 1941, pp. 261-263.

Material. - 1 o $33.98 \mathrm{~mm}$; approx. $13 \mathrm{mi}$. off Tg. Lelar, Trangan Island, Aru, $06^{\circ} 4^{\prime}$ 'S., $133^{\circ}$ 50'E.; dredged, 21-22 fms.; Sta. A. V/l-2,

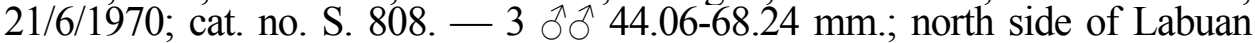
Olendir, Selaru Island, Tanimbar, $08^{\circ} 07^{\prime}$ S., $130^{\circ}$ 59'E.; shore collection; coral boulder; Sta. TS. IV, 26/6/1970; cat. no. S. 805-807.

Previous Maluku record. - This species has been recorded from various localities in Maluku (Sunier, 1918; Hansen, 1926; Hothuis, 1941).

Family Lysiosquillidae Giesbrecht, 1910

Genus Acanthosquilla Manning, 1963

Acanthosquilla derijardi Manning, 1969

Lysiosquilla multifasciata Tweedie, 1949, pp. 39-40, fig. 1a, b. (non Lysiosquilla multifasciata Wood-Mason, 1895). 
Acanthosquilla derijardi Manning, 1969b, pp. 1434-1438, fig. 2.

Material. - 1 ㅇ 34.12 mm.; north end of Kai Dulah Island, Kai, $05^{\circ}$ 29'S., $132^{\circ}$ 48'E.; dredged, 10-12 fms.; coarse sand; Sta. KR. IX/1-2, 12/6/1970; cat. no. S. 833.

Remarks. - The present specimen fully agrees with Manning's description for the species (Manning, 1969b). Raptorial claw armed with 6 teeth, penultimate shorter than antepenultimate, proximal tooth eventhough very small has the form of a tooth; outer margin of raptorial dactylus with two notches, distal notch much larger than proximal. Dorsal fan of telson with two groups of spines on either sides of the median spine; submedian 2-2, lateral 3-4. I have the opportunity to examine Dr. Tweedie's specimen which is deposited in the National Museum of Singapore (Cat. no. NMS. 1970.10.22.9). In Tweedie's specimen the proximal tooth of the raptorial claw is not very clear as a tooth, it is more close to a denticle. In Tweedie's material and the drawing of Manning (fig. 2) the eye-peduncles are partly covered by the rostral plate, in Maluku specimen peduncles are not covered.

Previous Maluku record. - None. This is a new record for the area.

\section{Acanthosquilla multifasciata (Wood-Mason, 1895)}

Lysiosquilla multifasciata Wood-Mason, 1895, pp. 2-3, pl. i, figs. 4-7. - Kemp, 1913, pp. 122-124. - 1915, pp. 175-176, pi. 1, figs. 2-3. - Chopra, 1939, pp. 162-165, fig. 8-9. - Holthuis, 1941, p. 274. - Tiwari and Biswas, 1951, pp. 360-361, text-fig. 4. - Stephenson, 1962, p. 34. - Ingle, 1963, pp. 33-25, figs. 21,42, 65, 73.

Acanthosquilla multifasciata Manning and Serene, 1968, pp. 115 (listed). - Manning, 1968a, p. 33 (in key).

Material. - 1 specimen, very badly damaged; Teluk Dodinga, north of Ternate Island, Halmahera, $00^{\circ} 49$ N., $127^{\circ} 33^{\prime}$ E.; dredged, 17-23 fms.; fine Acropora and mud; Sta. HD. I/I, 20/5/1970. - 1 त $44.72 \mathrm{~mm}$.; approx. 8 mi. southeast of Tg. Ratoe, Maikoor, Aru, 06 ${ }^{\circ} 07^{\prime} \mathrm{S} ., 133^{\circ} 57^{\prime}$ E.; dredged, 25 fms.; sand and rubble; Sta. AM. II/4-5, 18/6/1970; cat. no. S. 811. 2 ते 23.66-55.04 mm.; Jamdena Strait, east of Wotap, Tanimbar, $07^{\circ} 19^{\prime}$ S., $131^{\circ} 23^{\prime}$ E.; dredged, 35-40 fms.; mud; Sta. TJ. III/1-3, 23/ 6/1970; cat. no. S. 809-810. - 1 o $28.18 \mathrm{~mm}$.; Clarence Strait, south of Bathurst Island, Northern Territory, Australia, $12^{\circ} 01^{\prime} \mathrm{S} ., 130^{\circ} 08^{\prime} \mathrm{E}$.; dredged, 29-32 fms.; mud; stones an dead shells; Sta. B. I/I, 30/6/1970; cat, no. S. 816.

Previous Maluku record. - In Maluku the species has only been recorded from Piru Bay (Anonymous, 1972). It has been recorded from the Philippines (Kemp, 1915; Roxas and Estampador, 1930) and Australia (Stephenson, 1962). This is a new record for the area. 


\section{Acanthosqulla wilsoni new species}

(fig. 2 a, b, c, d).

Materiall. - Holotype; 1 ก 38.66 mm.; both raptorial claws missing; west of Babi Island, Wokam, Aru, 05 ${ }^{\circ} 54^{\prime}$ S., 134 $4^{\circ}$ 04'E.; dredged 40-42 fms.; mud; Sta. AW. V/3, 17/6/1970; cat. no. S. 836.

Description. - Eyes not extending to the end of antennular peduncle; cornea distinctly bilobed, set obliquely on stalk; ocular scales small, erect, apices divergent. Antennular peduncle short, about half as long as carapace (rostrum excluded); dorsal process of antennular somite visible on either side of rostral plate as a slender, anteriorly directed spine. Rostral plate ovate with pointed apex forming an anteriorly directed spine which fails to reach the base of cornea. Raptorial dactyla missing. Mandibular palp and five epipods present. Exposed thoracic somites smooth, lateral margin rounded; endopod of walking legs two-segmented, subcircular on the first two legs and ovate on the last. Abdomen depressed, somites broad, smooth; sixth somite less broad than the preceedings, posterolateral margin with a sharp spine, posterior margin on the intermediate portion armed with 2-3 spines; ventral projection overhanging the articulation of uropod armed with a spinule; ventral surface smooth. Telson broader than long; dorsal fan armed with 6-7 spines on either sides of median spine; margin armed with 4 fixed teeth and one pair of submedian movable tooth on either sides, denticles formulation are as follows: submediain 2, intermediate 1, lateral 1, marginal 1; area between dorsal fan and margin is thickly covered with spines and spinules in an irregular pattern. Anal opening situated on a raised area with two blunt posterolateral adges and somewhat triangular median notch. Uropod with 6 slender movable spines on outer margin of proximal segment of exopod, last not extending to middle of distal segment; inner spine of basal prolongation of uropod much longer than outer. Other measurements. - $\mathrm{Cl} .7 .40 \mathrm{~mm}$.; cornea width $1.18 \mathrm{~mm}$.; rostral plate: length $3.18 \mathrm{~mm}$., width $2.42 \mathrm{~mm}$.; telson: length $4.42 \mathrm{~mm}$., width $7.18 \mathrm{~mm}$.

Colour. - The whole dorsal surface is faintly pigmented with black, The pigmentation is more prominent on posterolateral angle of carapace, on posterior margin of eighth thoracic somite, first five abdominal somites and less prominent on posterior margin of seventh thoracic and sixth abdominal somites. The general colour pattern has the characteristics of the genus.

Discussion. - Acanthosquilla wilsoni is close to A. derijardi and A. midtifasciata. As mentioned by Manning (1969b) that $A$. derijardi and $A$. multifasciata are closely resembles to each other. The present species can be easily separated from the proceedings by: 1). the form of rostral plate which has an entire margin and sharp pointed apex, 2 ). the presence of 2-3 spines on intermediate posterior margin of sixth abdominal somite, 3 ). the presence of spines and spinules which covered the area between dorsal fan and marginal teeth in an irregular pattern. 


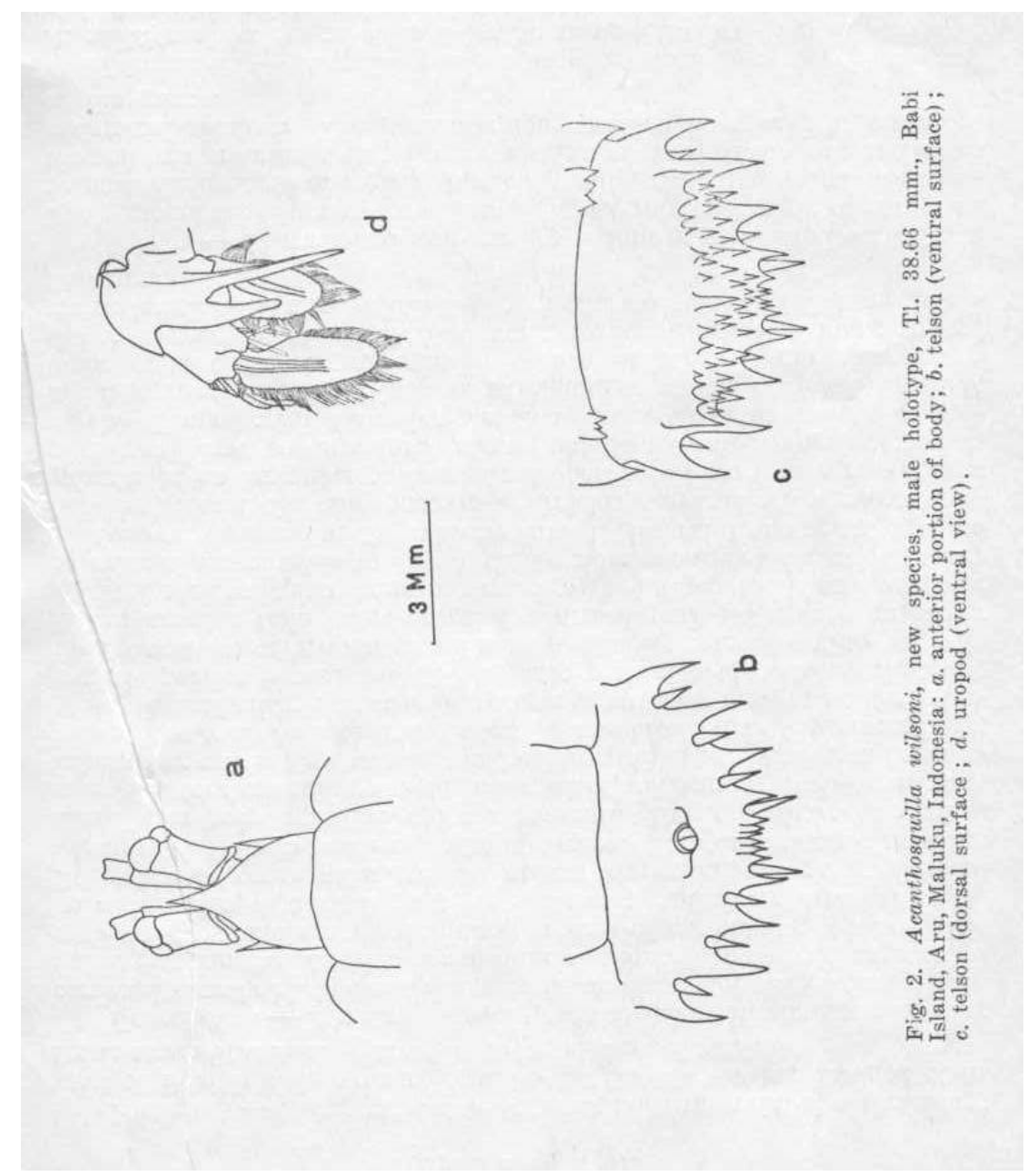


Type, - The holotype is deposited in the Institute of Marine Research, Jakarta

Type locality. - Aru Islands, Indonesia.

Etimology. - The species is named after Dr. Barry R. Wilson, the expedition leader.

Previous Maluku record. - Known only from the type locality.

$$
\begin{array}{llll}
\text { Family } & \text { SQUILLIDAE } & \text { Latreille, } & 1804 \\
\text { Genus Anchisquilla } & \text { Manning, } & 1968 \\
\text { Anchisquilla fasciata (De Haan, 1844) }
\end{array}
$$

Squilla fasciata Brooks, 1886, pp. 37-44, pl. ii, fig. 8, pi. iii, fig. 45.Kemp, 1913, pp. 33-36, pi. i, figs. 21-23. - Kemp and Chopra, 1921, p. 300. - Hansen, 1926, pp. 5-6. - Tweedie, 1934, pp. 35-36. - Bouvier, 1937, pp. 177-179, fig. 1. - Holthuis, 1941, pp. 242-243. - Serene, 1954, pp. 59-60, pi. iii, figs. 1-4.

Anchisquilla fasciata Manning and Serene, 1968, p. 116 (listed).

Material. — 1 त (Cl. $11.68 \mathrm{~mm}$., partly damaged), 1 क $52.72 \mathrm{~mm}$.; 7-12 mi. west of Toba Island, Aru, $05^{\circ} 23$ 'S., 134 ${ }^{\circ} 17^{\prime} \mathrm{E}$.; dredged, 30-35 fms.; mud; Sta. AT. II/3-4, 16/6/1970; cat. no. S. 834-835.

Previous Maluku record, - Holthuis (1941) mentioned a specimen from Molucca but without definite position. It has been recorded from the surrounding waters.

\section{Genus Carinosquilla Manning, 1968 \\ Carinosquilla multicarinata (White, 1847)}

Squilla multicarinata Kemp, 1913, pp. 86-88, pi. iv, figs 73-76. Sunier, 1918, p. 9. - Kemp and Chopra, 1921, p. 307. - Tweedie, 1934, p. 39. - Stephenson, 1962, pp. 33-36. (listed).

Carinosquilla multicarinata Manning and Serene, 1968, p. 116

Material. - 1 ㅇ $30.92 \mathrm{~mm}$; off Tg. Tutuhuhur Piru Bay, Ceram, $03^{\circ} 15^{\prime} \mathrm{S} .,{ }^{\circ} 128^{\circ} 08^{\prime} \mathrm{E}$.; dredged, 32-35 fms.; coarse foraminiferal and shell sand; Sta. CP. I/I, 1/6/1970; cat. no. S. 682.

Previous Maluku record. - None. This is a new record for the area.

Genus Clorida Eydoux and Souleyet, 1841

Clorida chlorida (Brooks, 1886)

Squilla chlorida Brooks, 1886, pp. 40-44, pi. ii, figs. 1-5. - Kemp, 1913 , p. 33. -

Clorida chlorida Manning, 1968a, pp. 5-8, fig. 1. - Manning and Serene, 1968, p. 116 (listed).

Material. - $1943.02 \mathrm{~mm}$.; Teluk Dodinga, north of Ternate, Halmahera, $00^{\circ} 49^{\prime}$ N., $127^{\circ} 33^{\prime}$ E.; dredged, 17-23 fms.; fine Acropora and mud; Sta. HD. I/I, 0/5/1970; cat. no. S. 685 . - 1 q $49.24 \mathrm{~mm}$; off west 


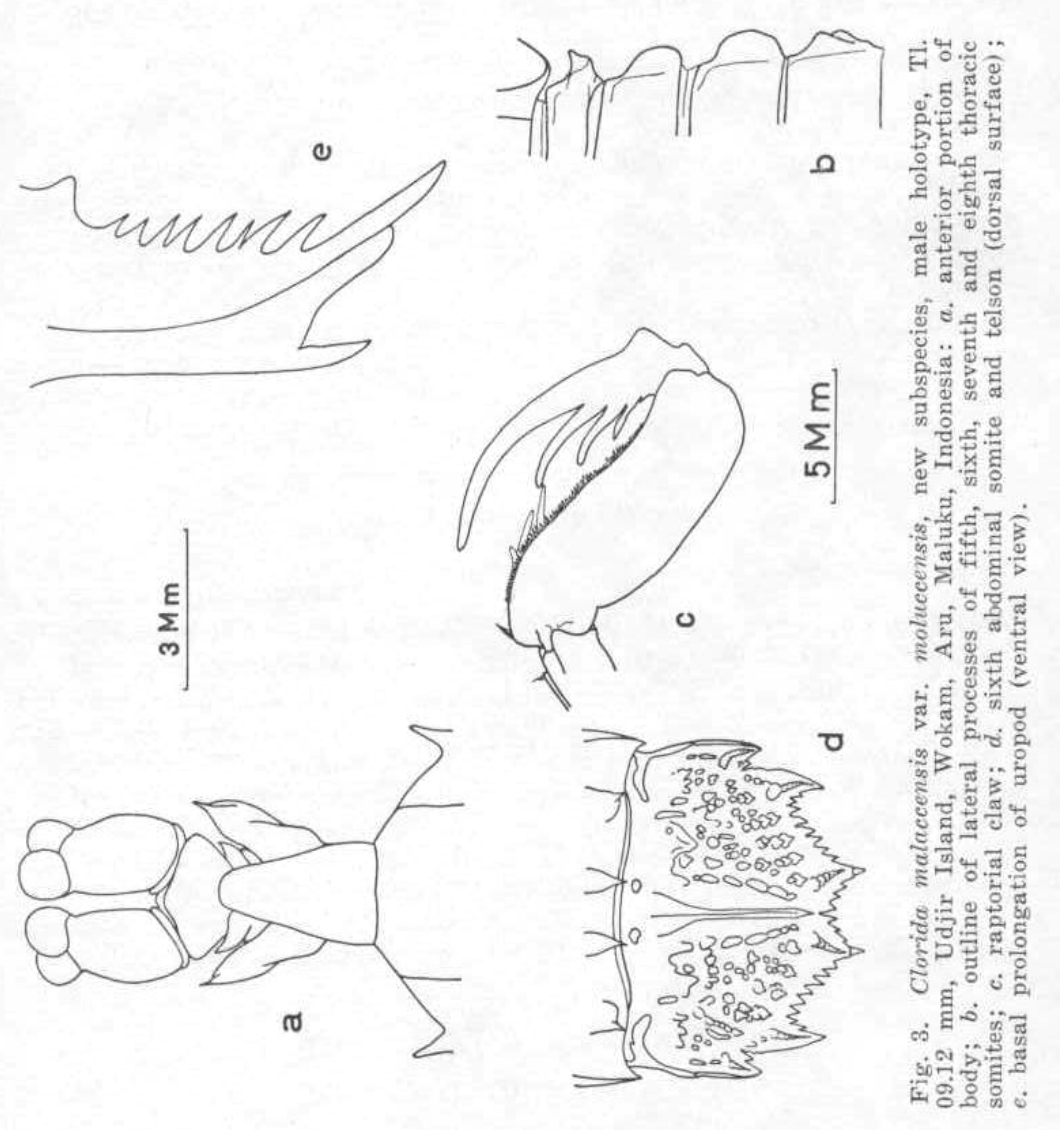


coast of Udjir Island, Wokam, Aru, 05³7'S., 134 ${ }^{\circ} 10^{\prime} E$.; dredged, 30-36 fms.; sand and fine shelly girt; Sta. AW. IV/1-3, 16/6/1970; cat. no. S. 684. - 1 त $31.80 \mathrm{~mm}$; ; west of Tg. Ratoe, Maikoor, Aru, $06^{\circ} 01^{\prime} \mathrm{S} ., 1^{\circ} 4^{\circ} 00^{\prime}$ E.; dredged, 60 fms.; Sta. AM. I/I, 17/6/1970; cat. no. S. 686. - 1966.08 $\mathrm{mm}$.; west of $\mathrm{Tg}$. Ratoe, Maikoor, $06^{\circ} 01^{\prime} \mathrm{S} .,{ }^{\circ} 134^{\circ} 00$ E.; dredged, 35 fms.; Sta. AM. 1/2, 17/6/1970; cat. no. S. 687. - 1 त $19.40 \mathrm{~mm}$; approx. $5 \mathrm{mi}$. north of Labuan Olendir, Selaru Island, Tanimbar, $08^{\circ} 03^{\prime} \mathrm{S} .,{ }^{\prime} 130^{\circ} 56^{\prime} \mathrm{E}$.; dredged, 28-32 fms.; sandy-mud; Sta. TS. 1/2, 25/6/1970; cat. no. S. 689 . - $1{ }^{\lambda} 24.42 \mathrm{~mm}$; approx. $5 \mathrm{mi}$. north of Labuan Olendir, Selaru Island, Tanimbar, $08^{\circ} 03^{\prime} \mathrm{S}$., $130^{\circ} 56^{\prime} \mathrm{E}$; dredged, $30 \mathrm{fms}$.; fine mud; Sta. TS. 1/3-4, 26/6/1970; cat. no. S. 688.

Remarks. - The specimens agree with the description of Brooks (1886) and Manning (1968a) with some modications: 1). the spinulation formula of the abdominal carinae is as follows: submedian 6; intermediate (4), 5, 6, lateral (4), 5, 6, and marginal (4), 5, 2). Denticles formulation is as follows: submedian 2-3, intermediate 6-7 and marginal 1,3 ). outer margin of proximal segment of uropodal exopod armed with 7-8 movable spines, the last extending beyond midlength of distal segment, 4). basal prolongation of uropod with 8-9 slender spines on inner margin, the lobe between the two spine is broad.

Previous Maluku record. - The type was collected from Amboina (Brooks, 1886). The present record shows the species wide distribution in Maluku waters.

\section{Clorida malaccensis var. moluccensis new subspecies}

$$
\text { (fig. 3, a, b, c, d, e) }
$$

Clorida malaccensis Manning, 1968b, pp. 244-247, fig. 2.

Material - Holotype: 1 o $69.12 \mathrm{~mm}$.; off west of Udjir Island, Wokam, Aru, $05^{\circ} 37^{\prime} \mathrm{S}$., $134^{\circ} 10^{\prime} \mathrm{E}$.; dredged, 30-36 fms.; mud and fine shelly grit; Sta. AW. IV/1-3, 16/6/1970; cat. no. S. 846. - Paratype: 1 त $71.08 \mathrm{~mm}$.; Arafura Sea, $04^{\circ} 52 \mathrm{WS}, 135^{\circ} 25^{\prime} \mathrm{E}$.; trawled, $90 \mathrm{~m}$.; mud and sand; coll. M.K. Moosa, 28/6/1964; cat. no. S. 022.

Description. - Eyes small, elongate, extending to the end of the first segment of antennular peduncle; stalk .slightly inflated, not as broad as cornea; cornea small, bilobed, breadth about 'two-thirds the length of the eye; ocular scale wide, pentagonal, with anterolateral angles rounded and anterior angle truncate, fused along midline. Antennular peduncle elongate, about three-fourths the length of carapace; dorsal processes of antennular somite visible lateral to rostral plate as a stout, sharp, anteriroly directed spine. Antennal peduncle not extending beyond the eye; antennal scale slender, less than half the length of carapace. Rostral plate about twice longer than broad, margins proximally paralell, distally convergent to form a rounded apex; median carina absent. Carapace narrowed anteriorly, lacking dorsal carinae except the reflected marginal carina on posterior part; anterolateral spines fail to reach the base of rostral plate. Raptorial claw stout; dactylus armed with four 
teeth, outer margin with two notches, distal notch larger than proximal; dorsal ridge of carpus terminating in a small, low, blunt tubercle. Mandibular palp and four epipods present. Exposed thoracic somites lacking submedian carinae; last three somites with sharp, unarmed intermediate carinae; lateral process of fifth somite sharp, directed anterolaterally, ventral tooth present, spinous; lateral process of the sixth and seventh somites rounded posteriorly, not bilobed; ventral keel on the eighth somite prominent, acute, projecting ventrally. Abdomen lacking submedian carinae on the first five somites; sixth somite with a small ventrolateral spine in front of articulation of each uropod, a tubercle present between submedian and intermediate carinae. The spine formulation of the abdominal carinae is as follows: submedian 5; intermediate 5,6; lateral 5,6; marginal 5. Telson broader than long, armed with three pairs of sharp marginal teeth; submedian teeth with movable apices; praelateral lobe absents; carina of the submedian and intermediate teeth tuberculate, carina of the marginal teeth smooth and swollen; outer margin of intermediate teeth denticulate; base of intermediate and lateral teeth swollen. Telson ornamented dorsally with 6-7 rows of curved tubercles; median carina terminating posteriorly in a sharp spine, submedian carinae tuberculate, converging posteriorly to form a U-shape; denticles sharp, formulation is as follows: submedian 3-4, intermediate 7-8, lateral 1. Ventral surface of telson with marked post-anal keel surrounded by tubercles in one definite row and outer row irregularly arranged. Outer margin of proximal segment of uropodal exopod with 6 slender, curved, movable spines, the last not extending to midlength of distal segment; proximal segment of exopod with longitudinal dorsal carina; endopod slender, curved; basal prolongation armed with 5-9 slender spines on inner margin and a lobe present on outer margin of the longer inner spine.

Other measurements. - Holotype: Cl. $13.54 \mathrm{~mm}$; anterior width of carapace $5.68 \mathrm{~mm}$., posterior width $12.38 \mathrm{~mm}$.; cornea width $1.64 \mathrm{~mm}$.; eyepeduncle width $1.62 \mathrm{~mm}$.; eye length $2.48 \mathrm{~mm}$; rostrum: width $1.88 \mathrm{~mm}$., length $3.28 \mathrm{~mm}$; telson: width $13.98 \mathrm{~mm}$., length $9.36 \mathrm{~mm}$. Paratype: Cl. $13.86 \mathrm{~mm}$; anterior width of carapace $5.718 \mathrm{~mm}$., posterior width 13.12 $\mathrm{mm}$; cornea width $13.12 \mathrm{~mm}$; eye-peduncle width $1.66 \mathrm{~mm}$.; eye length $3.04 \mathrm{~mm}$.; rostrum: width $1.96 \mathrm{~mm}$., length $3.54 \mathrm{~mm}$.; telson: width 14.04 mm., length $9.96 \mathrm{~mm}$.

Discussion. - The specimens have very close resemblances to Clorida malaccensis as described and figured by Manning (1968b, fig. 2). The marked differences which can be easily seen are: 1). the form of the ocular scale which in C. malaccensis is rounded and clearly consists of two fused lobes, in Maluku specimens these lobes are fused and resemble and undivided pentagonal form, 2). dactylus armed with only four teeth, the small proximal tooth which is present in the type of malaccensis is lacking. The very close resemblances between the Maluku specimens and $C$. malaccensis indicate its close relationship but the above mentioned differences can be used to separate the Maluku specimens into different subspecies. 

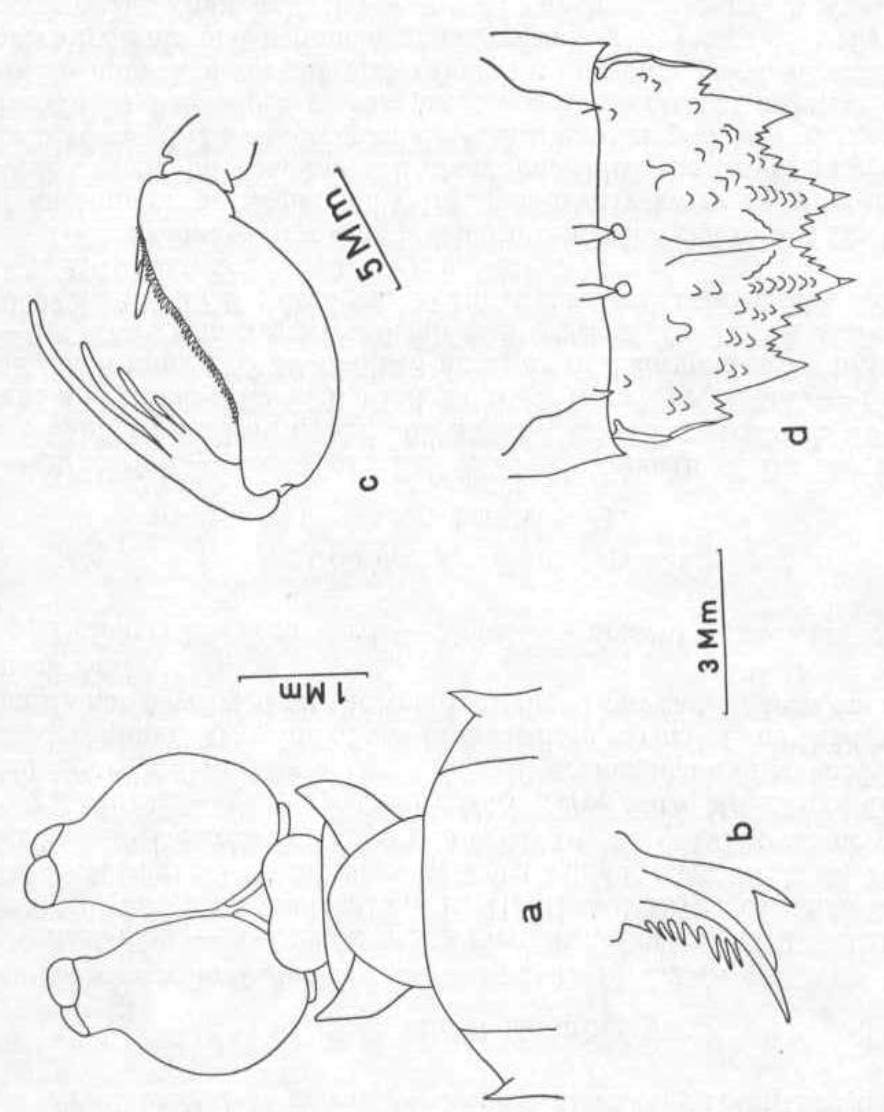

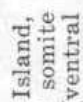

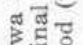

우의 항

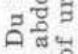

후류

乐, 致

लें 웅

욜

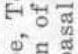

อั 5

范

항

ㅎํㄹ

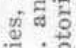

욜

कू.

政

क्ष

हैं

क

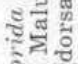

8ิ

들

- ज्ञ

iㅡ. 
Type, - The holotype and paratype are deposited in the Institute of Marine Research, Jakarta.

Type locality. - The holotype was collected from Aru Islands, Indonesia. The paratype was collected in the Arafura Sea, Indonesia.

Etimology. - The name moluccensis refers to the occurrence of this subspecies in Maluku waters.

Previous Maluku record. — None. Known only from the type locality.

\section{Clorida miersi Manning, 1968}

Clorida miersi Manning, 1968a, pp. 11-14, fig. 3.

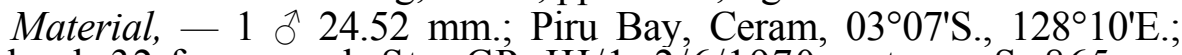
dredged, 32 fms.; mud; Sta. CP. III/1, 2/6/1970; cat. no. S. 865. 1 त $20.46 \mathrm{~mm}$.; 7-12 mi. west of Toba Island, Aru, $05^{\circ} 23^{\prime} \mathrm{S} ., 134^{\circ} 17^{\prime} \mathrm{E}$.; dredged, 30-35 fms.; mud; Sta. AT. II/3-4, 14/6/1970; cat no. S. 864.

Remarks. - The specimens fully agree with Manning's description and figure with a few notes: 1). basal prolongation of uropod bears 6-7 slender spines, 2). spine of the intermediate carina of the fifth abdominal somite not developed on the small specimen but can be seen on the larger specimen.

Previous Maluku record. - None. The present record is a new record.

\section{Clorida seversi new species}

(fig. 4 a, b, c, d).

Material. - Holotype: 1 o $31.78 \mathrm{~mm}$.; north of Du Rowa Islands, north of Nuhu Rowa, Kai, $05^{\circ} 32^{\prime}$ S., 132 ${ }^{\circ} 41^{\prime}$ E.; dredged, 15-20 fms.; sand and rubble; Sta. KR. VI/3, 11/6/1970; cat. no. S. 850. - Paratypes: 1 त $20.48 \mathrm{~mm}$., 2 우 30.32-30.38 mm.; as in holotype; cat. no. S. 847-849. - 1 त $27.24 \mathrm{~mm}$.; approx. 8 mi. southwest of Tg. Ratoe, Maikoor, Aru, $06^{\circ} 07^{\prime}$ S., $135^{\circ} 57^{\prime}$ E.; dredged, 25 fms.; sand and rubble; Sta. AM. II/4-5, 18/6/1970; cat. no. S. 845 .

Description. - Eye small, fails to reach the end of the first segment of antennular peduncle; stalk inflated, nearly twice as wide as cornea; cornea small, bilobed, breadth about one-third the length of eye; ocular scale rounded, fused along midline. Antennular peduncle elongate, about four-fifths the length of carapace; dorsal process of antennular somite visible lateral to rostral plate, forming an acute point, directed anterolaterally. Antennal peduncle short, extending to the middle of eye; scale slender, less than half the length of carapace. Rostral plate triangular with rounded apex, broader than long, median carina absent. Carapace narrowed anteriorly, lacking dorsal carinae except for the marginal reflected carinae on posterior part; anterolateral angle with sharp spine which fails to reach base of rostral plate. Raptorial claw slender; dactylus armed with four teeth which are not widely separated; propodus inflated, outer margin strongly curved; dorsal ridge of carpus entire, terminating in a low, small tubercle. Mandibular palp absent. Four epipods present. 
Exposed thoracic somites lacking submedian carinae; lateral process of the fifth somite acute, directed anterolaterally, ventral spine absent; lateral process of the sixth and seventh somites rounded posteriorly, not bilobed; ventral keel on the eighth small and acute, projecting ventrally. Abdomen smooth, highly polished; first five abdominal somites without submedian carinae. Abdominal carinae spined as follows: submedian 6; intermediate (5), 6; lateral 6. Telson broader than long, armed with three pairs of marginal teeth; submedians with movable apices; praelateral lobe absent; carinae of submedian and intermediate teeth tuberculate; median carina sharp, terminating in a sharp spine; submedian carinae tuberculate; a small tubercle present below the spine of the median carina; dorsal surface ornamented with 6-7 rows of tubercles; denticles sharp, formulation as follows: submedian 4, intermediate 5-7, lateral 1. Ventral surface of telson smooth, postanal keel present. Outer margin of proximal segment of uropodal exopod with 6 slender, curved, movable spines, last not extending to midlength of the distal segment; endopod slender, sligthly curved; basal prolongation armed with 7-9 slender spines on inner margin, a lobe present on outer margin of inner longer spine.

Measurements. - Holotype: Cl. $6.34 \mathrm{~m}$.; anterior width of carapace $3.38 \mathrm{~mm}$.; posterior width $6.26 \mathrm{~mm}$.; cornea width $0.64 \mathrm{~mm}$.; eyepeduncle width $1.26 \mathrm{~mm}$; ; eye-length $2.24 \mathrm{~mm}$; rostral plate: width 1.34. mm., length $1.02 \mathrm{~mm}$; ; telson: width $6.94 \mathrm{~mm}$., length $4.82 \mathrm{~mm}$.

Colour. - The species is evenly and symmetrically pigmented. The areas with heavy pigmentation are: rostral plate, ventral portion of carapace between the two gastric grooves, posterior end of proximal segment of uropod, anterior end of distal segment of exopod and outer portion of endopod.

Discussion. - Following Manning's key for the species (Manning, $1968 \mathrm{a}, \mathrm{pp}$. 4-5) the specimens will come to Clorida granti (Stephenson). The other Clorida which do not posses mandibular palp are C. incerta (Hansen), C. denticauda (Chapgar and Sane), C. mauiana (Bigelow) and $C$. fallax (Bouvier). The new pecies can be separated from $C$. incerta by comparing the breadth of cornea to the width of eye-stalk and by the absence of median keel on rostral plate. From $C$. denticauda it can be separated by the absence of teeth on outher margin of intermediate denticle of telson, the form of the ocular scales, the form of basal prolongation of uropod and by the form of the lateral process of the fifth thoracic somite. It can be separated from $C$. mauiana and $C$. fallax by having only one lobe between the two spines of the basal prolongation of uropod. From $C$. granti it can be separated by: 1). the eyes almost reach the end of the first antennular segment, in granti the eyes reach less than half the length of the segment of the antennular penducle, 2 ). the articulation of ischium and merus of raptorial limb is terminal, in granti it is in advance of the proximal end of merus, 3 ). lateral process of the fifth thoracic somite directed anterolaterally instead of directed outwardly as in granti, 4). the spine formulation of the species is as 
follows: $C$. granti: submedian 6; intermediate 5-6, lateral (4)-6, marginal 4-5; in seversi: submedian 6; intermediate (5)-6; lateral 1 . The above mentioned differences are sufficient to establish the specimens as a new species.

Type. - The holotype and paratypes are deposited in the Institute of Marine Research, Jakarta.

Type locality. - Kai Islands, Indonesia.

Etimology. - The name seversi is dedicated to Mr. Leon R. Severs, the ship captain. lty.

Previous Maluku record. - None. Known only from the types loca-

\section{Genus Oratosquilla Manning, 1968}

Oratosquilla gonypetes (Kemp, 1911)

Squilla gonypetes, Kemp, 1911, pp. 96-97, - 1913, pp. 54-55, pl. iv, figs. 42-44. - Sunier, 1918, pp. 5-6. - Kemp and Chopra, 1921, pp. 300-301. - Hansen, 1926, p. 10. - Stephenson, 1962, p. 35. - Ingle, 1963 , p. 15, figs. 1, 5, 14. - Manning, 1965, pp. 250-253, pl. xi, fig. b. - 1968, pp. 24-25, fig. 7.

Oratosquilla gonypetes, Manning and Serene, 1968, p. 117 (listed).

- Manning, 1969, p. 15. - 1971, p. 14 (in key).

Material - 1 त $27.78 \mathrm{~mm}$.; west of Toba Island, Aru, $03^{\circ} 07^{\prime} \mathrm{S}$., $128^{\circ} 10^{\prime}$ E.; dredged, 20-29 fms.; mud. Sta. AT II/1-2, 14/6/1970; cat. no. S. 866 . - 1 + $20.34 \mathrm{~mm}$. (eyes missing) ; approx. $8 \mathrm{mi}$. southwest of Tg. Ratoe, Maikoor, Aru, 06 $07^{\circ}$ S., 135 57'E.; dredged, 33-35 fms.; sand and rubble; Sta. AM. II/8-11, 18/6/1970; cat. no. S. 867. - 1 + $31.78 \mathrm{~mm}$.; west of Tg. Derehi, Trangan Island, Aru, $06^{\circ} 26^{\prime} \mathrm{S} ., 1^{\circ} 3^{\circ} 57^{\prime} \mathrm{E}$.; dredged, 23-28 fms.; muddy-sand; Sta. A. 1/1-3, 19/6/1970; cat. no. S. 842. - 1 त $36.02 \mathrm{~mm}$. (eyes missing) ; approx. $5 \mathrm{mi}$. north of Labuan Olendir Selaru Island, Tanimbar, 08 $03^{\prime}$ 'S., 130 $136^{\circ}$ E.; dredged, $30 \mathrm{fms}$; fine mud; Sta. TS. 1/3-4, 26/6/1970; cat. no. S. 843.

Previous Maluku record. - The species has never been recorded from Maluku but was recorded from the surrounding waters. This is a new record for Maluku.

\section{Oratosquilla quadraticauda (Fukuda, 1911)}

Squilla quadraticauda, Fukuda, 1911, pp. 286-287, pi. xi, figs. 1-2. - Squilla hoops, Kemp, 1911, p. 97. - 1913* p. 55-57), pi. iv, figs. 45-47.

- Komai, 1938, p. 266.

Oratosquilla quadraticauda, Manning and Serene, 1968, p. 117 (listed).

- Manning, 1971, p. 14 (in key).

Material. - 1 o $38.72 \mathrm{~mm}$; approx. $8 \mathrm{mi}$. southwest of Tg. Ratoe, Maikoor, Aru, $06^{\circ} 07^{\prime} \mathrm{S} ., 133^{\circ} 57^{\prime} \mathrm{E}$.; dredged, $25 \mathrm{fms}$.; sand and rubble; Sta. AM. II/4-5, 17/1970; cat. no. S. 844.

Diagnosis. - Eye large, cornea bilobed, set transversely on stalk; eyes extending beyond end of the first segment of antennular peduncle; ocular scale small, with rounded margin, set abliquely; corneal index: 
224. Antennular peduncle slender, as long as carapace. Antennal scale slender, about two-thirds the length of carapace. Rostral plate triangular with rounded apex, as long as broad; median carina present on anterior part about one-third of rostral length. Carapace narrowed anteriorly, anterior breadth more than half median length of carapaee; anterolateral margin with small, sharp spine, not extending to base of rostral plate; median carina present, interrupted under the inconspicuous anterior bifurcation; intermediate carinae extending posteriorly as long as hall of its course; reflected marginal carinae present on posterior part. Mandibular palp and four epipods present. Raporial claw slender; dactylus armed with 5 teeth, outer margin smooth, slightly concave on porterior part, a small notch presents on proximal portion; propodus flattened and slightly inflated; dorsal ridge of carpus terminating in a high acute tooth. Exposed thoracic somites with submedian carinae on the last three somites; lateral process of fifth somite bilobed, anterior lobe with a sharp spine directed anterolaterally, posterior lobe acute; sixth and seventh somites bilobed anterior lobe small; ventral keel on eighth somite small, acute, projecting ventrally. Abdominal somites with submedian carinae; spine formulation is as follows: submedian 5-6, intermediate 3-6, lateral 2-6, marginal 1-5; sixth somite with sharp posterolateral spine in front of uropodal articulation. Telson broader than long; median carina sharp, terminating in a sharp spine; dorsal surface on either sides of median carina ornamented with curved lines of minute denticles; margin armed with three sharp teeth, submedian without movable apices; praelateral lobe presents, not projecting laterally; carinae on the marginal teeth smooth; denticles blunt, formulation: submedian 4 , intermediate 8 , lateral 1 . Outer margin of proximal segment of uropodal exopod with 7 graded, movable spines, last not extending to middle of distal segment; distal segment ovate; basal prolongation of uropodal exopod with a rounded lobe on inner margin of inner longer spine.

Colour. - The whole surface corvered with evently distributed black pigment which is not clearly marked. The general coloration is dull. On the fifth abdominal somite, between lateral and marginal carinae, a black spot presents on posterior margin. The same spot with less marked pigment presents on the sixth segment.

Discussion. - The specimen agree with the descriptions of Fukuda (1911) and Kemp (1911, 1913). In Kemp's specimen which is larger than Fukuda's and Maluku's specimen, the spine of the abdominal carinae looks more developed. The spine formulation of the Maluku specimen is fully agrees with Fukuda's specimen.

Previous Maluku record. - None. This is the first record for the area which shows the eastern distribution of the species. 


\section{REFERENCES.}

ANONYMOUS, 1972. Biological and Hydrological Observations in the Piru Bay, Ambon Bay and Buton Strait, Inst. Mar. Res. Oceanogr. Cruise Rep. 7: 1 - 27, 3 figs.

Balls, H., 192.1. Results of Dr. E. Mjobergs Swedish Scientific Expedition to Australia, 1910 - 1913. XXIX. Stomatopoda, Macrura, Paguridea, und Galatheidea. K. Svenska Vetensk. Akad. Handl, 61(10): 1-24.

BARNARD, K.H., 1950. Descriptive list of South African stomatopod Crustacea (mantis shrimp). Aymals S. Afr. Mus., 38: 834-864, text-figs. 1-4.

BigElOW, R.P,, 1894. Report on the Crustacea of the order Stomatopoda collected by the steamer Albatross between 1885-1891 and on other specimens in the U.S. National Museum. Proc. U.S. Nat. Mus. 17: 489-550; pis. 20-22, figs. $1-28$.

BigElow, R.P.. 1931. The Stomatopoda of the Southern and Eastern Pacific Ocean and the Hawaiian Islands. Bull. MUS. Compr. Zool. Harvard Coll., 72(4) : 105 - 191, 2pls., 10 figs.

Blumstein, R., 1970. New stomatopod crustaceans from the Gulf of Tonkin, South China Sea. Crustaceana, 18(2): $218-224$, figs. $1-5$.

Borradaile, L.A., 1898. On some crustaceans from the South Pacific. Part I. Stoma topoda. Proc. Zool. Soc. London, 1898: $32-38$ pis. 5-6.

BorRADAILE, L.A $\mathrm{V}_{\mathrm{V}}$ 1907. Stomatopoda from the western Indian Ocean. The Percy Sladen Trust Expedition to the Indian Ocean 1905 under the leadership of M. Stanley Gardiner. Trans. Linn. Soc. London, 12(2), ser zool.: 209-216, pl. 22.

BouviER, E.L., 1915. Decapodes marcheurs et stomatopodes recueillis a'P ile Maurice par M. Paul Carrie. Bull. Sci. France et Beige, ser. 7: 48(3): 178-318, figs. 1-42.

BROOKS, W.K., 1886. The Stomatopoda collected by H.M.S. "Challenger". Rep. Sci. Res. ."Challenger", zool. 16: J. - 116, pis. 1-16.

ChHAPGAR, B.F. and SANE, S.R., 1967. Two new species of Squilla (Stomatopoda) from Bombay. Crustaceana, 12(1) : 1 - 8, figs. 1-2.

CHOPRA, B., 1934. On the stomatopod Crustacea collected by the R. Pilot Service off the mouth of the River Hughly, together with some notes on other forms. Rec. Ind. Mus., 36: 17-43, 5 figs.

Chopra, B., 1939. Stomatopoda. John Murray Exped. 1933 - 1934 Sci. Rep. 6: 137 - 181, text-figs. 1-13.

DANA, J.D., 1852. Crustacea. U.S. Exploring Exped., 13(1) : 614 - 633, pl. 41.

Edmondson, C. H., 1921. Stomatopoda in the Bernice P. Bishop Museum. Occas. Pap. Bernice P. Bishop Mus., 7(13) : 281 - 302, 2 figs.

Edmondson, C.H., 1925. Crustacea of tropical central Pacific. Bull. Bernice P. Bishop Mus., 27: pp. 59 - 60.

Edmondson, C.H., 1946. Shore and reef fauna of Hawaii. Bernice P. Bishop Mas., spec. publ. 22: iii 4- 381, text-figs. 1-223.

Eydoux, A.M. and Souleyet, L., 1841. Voyage autour du monde, execute par M. Vaillant sur la corvette "La Bonite". Zool., 1, Crustacea: 262-266, pi. 5.

FUKUDA, T., 1910. Report on the Japanese Stomatopoda, with descriptions of two new species. Annotat. Zool. Japon., 7(12): 139-152, pl. 4.

FUKUDA, T.,. 1911. Further report on Japanese Stomatopoda with description of two new species. Annotat. Zool. Japon., 7(12): 283-290, pi. 3, 5 figs.

Gordon, I., 1935. On two new species of Crustacea from Christmas Island. Ann, Mag. Nat. Hist., 16(10) : 629 - 637, 3 figs.

GRAVIER, C, 1933. Sur une petite collection de Stomatopodes recueillis par M. Dawydoff dans les eaux Indochinoises. Bull. Mus. Hist. Nat., 5: 77 - 82, 6 figs.

Gravier, C, 1937. Stomatopodes des cotes d'Indochine. Ann hist. Oceonogr. Monaco, 17: 175-211, text-figs. 1-23. 
Hale, H.M., 1'924. Notes on Australian Crustacea. No. 1. Family Squillidae. Rec. Austr. Mus., 2(4) : 491 - 502, pi. 32 - 33, 4 figs.

Hale, H.M., 1929. Crustacea from Princesss Charlotte Bay, North Queensland. Isopoda and Stomatopoda. Trans. Roy. Soc. South. Australia, 53: 33-36, 1 fig.

HANSEN, H.J., 1926. The Stomatopoda of the Siboga Expedition. Siboga Exped. Monogr. 35: $1-48$, pis. $1-2$.

Heller, C, 1865. Crustaceen. Reise der osteeichischen Fregatte "Novara" urn die Erde in den Jahren 1857-1859. Zool, 2(3), pp. 124-127.

Henderson, J.R., 1893. A contribution to Indian carcinology. Trans. Linn. Soc. London, ser. 2, 5: 325-458, pis. 36-40.

HolthuIS, L.B., 1941. Biological results of the Snellius Expedition. XII. Stomatopoda of the Snellius Expedition. Temminckia, 6: 241 - 294, 9 figs.

Holthuis, L.B., 1953. Enumeration of the decapod and stomatopod Crustacea from Pacific coral islands. Atoll. Res. Bull, 24: 1 - 166.

HolthuIS, L.B., 1964. Preliminary notes on two new genera of Stomapoda. Cmstaceana. 7(2): 140-141.

Holthuis, L.B., 1967. Stomatopoda, I. Familia Lysiosquillidae and Bathysquillidae. In: H.E. Grunner \& L.B. Holthuis, Crustaceorum catalogus (1), ed. a: 1-28. Den Haag.

INCLE, R.W., 1963. Crustacea Stomatopoda from the Red Sea and the Gulf of Aden. Contr. to the knowledge of the Red Sea, no. 26. Bull. Sea Fishr Res. Sta.f Haifa, 33: 1-69, figs. 1-73.

JURICH, B., 1904. Die Stomatopoden der deutschen Tiefsee-Expedition. Wiss. Ergeb. der Deutschen Tiefseexped. "Valdivia", 1898-1899, 7: 361-408, pis. 25-30.

KEMP, S.W., 1911. Preliminary descriptions of new species and varieties of Crustacea Stomatopoda in the Indian Museum. Rec. Ind. Mus., 6: 93-100.

KEMP, S.W., 1913. An account of the Crustacea Stomatopoda of the Indo-Pacific region based on the collection in the Indian Museum. Mem. Ind. Mus., 4(1) : 1 - 217 , 10 pis, 10 text-figs.

KEMP, S.W., 1915. On a collection of stomatopod Crustacea from the Philippine Islands. Philippine J. Sol, sect. D, 10(3): 16:9'-187, 1 pi.

KEMP, S.W., 1915a. Fauna of the Chilka Lake: Stomatopoda. Mem. hid. Mas., 6: 193197.

KEMP, S.W., 1918. Zoological results of a tour in the Far East. V. Crustacea: Decapoda and Stomatopoda. Mem. Asiatic Soc. Bengal, 6: 296-297.

KeMP. S.W. and ChOPRA, B., 1921. Notes on Stomatopoda. Rec. hid. MILS., 22: 297-311.

KomaI, T., 1927. Stomatopoda of Japan and adjacent localities. Mem. Coll. Sci. Kyoto Imper. Univ. ser. B: 307 - 354, pis. 13 - 14. 2 figs.

Komai, T., 1938. Stomatopoda occuring in the vicinity of Kii Peninsula. Annot. ZooL Japon, 17(3-4): 264-275.

LANCHESTER, W.F., 1901. On the Crustacea collected during the Skeat Expedition to the Malay Peninsula. Proc. Zool. Soc. London, 2: 553-555.

LANCHESTER, W.F., 1903. Marine crustaceans. VIII. Stomatopoda with an account of the varieties of Gonodaotylus chiragra. The fauna and geography of the Maldive and Laccadive Archipelagoes ed. by J. Stanley Gardiner 1: 444 - 458 $\mathrm{pl}, 23$.

LANCHESTER, W.F., 1906. Report on the Crustacea. Fasc. Malayensis, ZooL, 3: 1-13.

LENZ, H., 1910. Crustaceen von Madagaskar, Ostafrika und Ceylon. In; A. Voeltzkow, Reise in Ostafrika in den Jahren 1903-05, 2: 570-572.

LLYOD, R.E., 1907. Contributions to the fauna of the Arabian Sea, with descriptions on new fishes and Crustacea. Rec. Ind. Mus., 1(1) : 1-12.

LunZ, G.R, 1937. Stomatopoda of the Bingham Oceanographic collection. Bull. Bingham Oceanogr. Coll., Peabody Mus. Nat. Hist. Yale Univ., 5(5) : 1-19, 10 figs. 
MAN, J.G. DE, 1887. Bericht uber die von Herrn Dr. G. Brook im Indischen Archipel gesammelten. Dekapoden und Stomatopoden. Arch. Natunrgesch., 53(1): $571-583$.

MAN, J.G. DE, 1898. Dekapoden und Stomatopoden von Malaka, Borneo und Celebes. Zool. Jb. Abt. Syst., 10: 691-695.

Man, J.G. DE, 1902. Die von Herrn Prof. Kukenthal im indischen Archipel gesammelten Dekapoden und Stomatopoden. Abh. Senckenberg. Naturf. Ges. Frankfurt, 25: 910-921, pi. 27.

MAn, J.G. DE, 1929. Decapoda and Stomatopoda from Pulau Berhala. Misc. Zool. Sumatrana, 36: 1-3.

MANNING, R.B., 1962. Stomatopod Crustacea collected by the Yale Seychelles Expedition, 1957-58. Postilla Yule Peabody Mus. Nat. Hist., 68: 1-15, figs. 1-2.

Manning, R.B., 1963. Preliminary revision of the Pseudosquilla and Lysiosquilla with description of six new genera (Crustacea: Stomatopoda). Bull. Mar. Set. Gulf and Caribb., 13(2) : 308 - 328.

MAnning, R.B., 1965. Stomatopoda from the collection of His Majesty the Emperor of Japan. Crustaceans, 9(3): 249-262, pis. 11-12, figs. 1-2.

Manning, R.B., 1966. Notes on some Australian and New Zealand stomatopod Crustacea, with an account of the species collected by the fisheries investigation ship "Endeavour" Rec. Austr. Mus.y 27(4): 79-137, figs. 1-10.

Manning, R.B., 1967. Preliminary account of a genus and a new family of Stomatopoda. Crustaceana, 13(2): $238-239$.

MANNing, R.B., 1967a. Review of the genus Odontodactylus (Crustacea: Stomatopoda). Proc. U.S. Nat. Mus., 123(3606) : 1-35, figs. $1-8$.

MANning, R.B,, 1967b. Notes on the demanii section of the genus Gonodactylus Berthold with descriptions of three new spiecies (Crustacea, Stomatopoda). Proc. U.S. Nat. Mus., 123(3618): 1-27, figs, 1-8.

Manning, R.B., 1967c. Stomatopoda in the Vanderbilt Marine Museum. Crustaceana, 12(1): $102-106$.

Manning, R.B., 1968. A revision of the family Squillidae (Crustacea, Stomatopoda), with description of eight new genera. Bull. Mar Sc, 18(1) : $105-142$ figs. $1-10$.

Manning, R.B,, 1968a. Stomatopod Crustacea from Madagascar. Proc. U.S. Nat Mus., 124(3641): 1-6, figs. 1-16.

Manning, R.B.,, 1968b. Three new Stomatopod crustaceans from the Indo-Malaya area. Proc. Biol. Soc. Washington, 81: 241-250, 3 figs.

Manning, R.B., 1969. Notes on some stomatopod Crustacea from South-Africa. Smithsonian Contrib. Zool. 1: 1-7, 4 figs.

MANNING, R.B., 1969a. Notes on the Gonodactylus section of the family Gonodactylidae (Crustacea, Stomatopoda), with descriptions of four new genera and a new species. Proc. Biol. Soc. Washington, 82: 143-166, 8 figs.

Manning, R.B.13 1969b. Some stomatopod Crustaceans from Tulear, Madagascar. Bull. Mus. Nat. Hist. Natr., 2nd serie, 41(6): 1429-1441, figs. 1-3.

Manning, R.B,, 1970. A new genus and species of stomatopod crustacean from Madagascar. Bull. Mus. Nat. Hist. Nat. Ser. 2, 42(1): $206-209,1$ figs.

Manning, R.B., 1971. Keys, to the Species of Oratosquilla, (Crustacea: Stomatopoda), with descriptions of two new species. Smithsonian Contrib. Zool., 71: 1-'16, figs. $1-4$.

Manning, R.B., 1971a. Two new species of Gonodactylus (Crustacea, Stomatopoda), from Eniwetok atoll, Pacific Ocean. Proc. Biol. Soc. Washington, 81(10): 73-80, figs. $1-2$.

Manning, R.B., and Serene, R., 1968. Prodromus for a checklist of the non-planctonicmarine fauna of South East Asia. Singapore Nat, Acad. ScL, Spec. Publ. 1: 113-118. 
Miers, E.J., 1880. On the Squillidae, Ann. Mag. Nat. ist., 5(5) : 1 - 30, 108 - 127, pis. 1 - 3.

Miers, E.J., 1880a. On a collection of Crustacea from the Malaysian region: Stomatopoda. Ann. Mag. Nat. Hist., 5(5) : $458-460$.

Muller, F., 1886. Zur Crustaceenfauna von Trincomali. Verh. Naturw. Ges. Basel., 8: 417, 476-479,

Nobili, G., 1900. Decapodi e Stomatopodi Indomalesi. Ann. Mus. Civ. Storia Nat, $40(20): 519$.

Nobili, G., 1901. Nota intorna ad una collezione di crostacei di Sarawak (Borneo). Bull. Mus. Zool. Anat. Compar., 16(397) : 14.

Nobili, G., 1903. Contributo alia fauna carcinologica di Borneo. Bull. Mus. Zool. Anat. Compar., 18(447): 1-32. figs. 3. Torino 1903.

Nobili, G., 1903a. Crostacei di Singapore, Boll. Mus. Zool. Anat. Compar., 18(445) : $1-39$.

Nobili, G., 1906. Mission Bonnier et Perez, Golfe Persique 1901 Crustaces Decapodes et Stomatopodes. Bull. Sci. France et Belgique., 40: 157-159.

Ortmann, R.E., 1894. Crustaceen. In: Semon Zoollogische Forschungsreise in Australien und Malayischen Archipel, Band 5. Denkschr. Medizin. Naturw. Ges., 8: 6061 .

Pocock, R.J. 1893. Report upon the stomatopod crustaceans obtained by P.W. BassettSmith Esq. during of H.M.Sh. "Penguin". Ann. Mag. Nat. Hist, ser, 6, 11: $473-479$, pi. 20 b.

Roxas, H.A. and Estampador, E.. 1930. Stomatopoda of the Philippines. Nat. Applied Sci. Bull, 1: 93

Schmitt, W.L., 1929. Chinese stomatopods, collected by S.D. Light. Lingnan Sci. J., 8: 127-148, 4 pis.

Sendler, A., 1923. Die Dekapoden und Stomatopoden der Hanseatischen Sudsee Expedition. Abh. Senckenberg. Nat. Ges. Frankfurt., 38: 47.

SERENE, R., 1937. Inventaire des invertebrates marine de 1' Indochine. Note de 1' Inst Oceanoger. V Indochine., 30: 68.

Serene, R., 1939. Notes sur les Stomatopodes des eaux Indochinoises. Bull. Soc. Zool. France., 64: 343 - 349, 4. figs.

Serene, R., 1947. Sur des Stomatopodes rares trouves en Indochine et n'existen pas les collections du Museum. Bull. Mus. Hist. Nat., ser. 2., 19(5) : 381 - 389, 4 pis.

Serene, R., 1949., Observations sur le Gonodactylus strigatus Hansen (Crustaces Stomatopodes). Bull. Soc. Zool. France., 73(4-5): 225-231, 1 fig.

Serene, R.., 1950. Deux nouvelles especes Indo-Pasifique de Stomatopodes. Bull. Mus. Hist. Nat. Paris., 22(5): 571-572.

Serene, R.. 1951. Observations sue deux Pseudosquilla d' Indochine Treubia, 2: 11-25, 8 figs.

Sereine, R., 1952. Etude d' une collection de Stomatopodes de 1' Australian Museum de Sydney. Rec. Austr. Mus., 23(1): 1-24, text-figs. 1 - 33, pls. 1 - 3.

Serene, R., 1954. Observations biologiques sur les Stomatopodes. Ann. Inst. Oceanogr. Monaco., 29: 1-94, pls. 1-10, text-figs 1-15.

Serene, R., 1954a. Sur la collection de Stomatopodes. Mem. Inst. Oceanogr. Nhatrang., 8: $1-93$, figs. $1-15$, pls. 1-10.

Serene, R., 1962. Revision du genre Pseudosquilla (Stomatopoda) et definition de genrea nouveaux. Bull. Inst. Oceanogr. Monaco., 1241: 1-27 tex-figs. 1-5.

Stephenson, W., 1952. Faunistics records from Queensland. Part I General Introduction. Part II. Adult Stomatopoda (Crustacea). Zool. Pap. Univ. Queensland., 1(1): $1-15$.

Stephenson, W.., 1953. Notes on the Australian Stomatopoda (Crustacea) in the collection of Queensland Museum. Mem. Queensland Mus., 13(1): $40-49$. 
Stephenson, W., 1953a. Three new Stomatopoda from Eastern Australia. Austr. J. Mar. Freshw. Res., 4(1) : 201 - 218. Text-figs. 1 - 4.

Stephenson, W., 1955. Notes on the stomatopod Crustacea from Victoria and Tasmania, Mem. Nat. Mus. Melbourne., 19: 1-4.

StePhenson, W., 1960. Notes on Queensland Stomatopoda (mantisprawns). Queensland Naturalist, 16(3-4): 61 .

Stephenson, W., 1962. Some interesting Stomatopoda, mostly from Western Australia. J. Roy. Soc. W. Austr. 45(2): 33 - 43, text-figs 1 - 2, pl. 1.

Stephenson, W. and McNBill, F., 1955. The Australian Stomatopoda (Crustacea) in the collection of the Australian Museum. Rec. Austr. Mus., 2,3(5) : $239-265$, fig. 1.

SUNIER, A.J., 1918. The Stomatopoda of the collection of the Visscherij Station at Batavia. Contr. Faune Indes Neerlandaises, 1(4) : 62 - 75, figs. 1 - 4.

TAte, R., 1883. Descriptions of some new species of Squilla from South Australia. Trans. Proc. Roy. Soc. South. Austr., 48-53, pi. 2.

TAtTersall, W.M., 1906. Report on the Leptostraca, Schizopoda and Stomatopoda collected by Prof. Herdman at Ceylon in 1902. Rep. Pearl Oyster fish, by W.A. Herdman. 5: 166-188, pis. 1, 3.

Tirmizi, N.M. and Manning, R.B., 1968. Stomatopod Crustacea from West Pakistan. Proc. U.S. Nat. Mus., 125(3666) : 1-48, 17 figs.

TIWARI, K.K., and BISWAS, S., 1952. On two new species of the genus Squilla Fabr., with notes on other stomatopods in the collections of the Zoological Survey of India. Rec. Ind. Mus., 49(3 - 4) : 349 - 363. figs. 1-5.

TweEdie, M.W.F., 1934. Notes on the Stomatopoda in the Raffles Museum. Bull. Raffles Mus. Singapore., 9: 31 - 41.

TWEEDIE, M.W.F., 1935. Two new species of Squilla from Malaysian waters. Bull. Raffles Mus. Singapore, 10: 45-52. 1. pl.

TweEdie, M.W.F. 1949. Additions to the collections of the Stomatopods in the Raffles Museum. Bull. Raffles Mus. Singapore., 19: 39 - 41.

TweEdIE, M.W.F., 1950. The fauna of the Cocos-Keeling Islands,, Brachyura and Stomatopoda. Bull. Raffles Mus. Singapore, 2:2: 139-141.

WARD, M., 1942. Notes on the Crustacea of the Desjardins Museum, Mauritius Institute, with descriptions of new genera and species. Mauritius Inst. Bull., 2: 49- 113.

White, A., 1848. Descriptions of two new species of Crustacea Proc. Zool. Soc. London: 144, , pi. VII, figs. 1, la.

Whitelegge, T., 1897. The Crustacea of Funafuti. Mem. Austr. Mus. 3: 148.

Whitelegge, T., 1900. Contributions to a knowledge of the fauna of British New Guinea, Crustacea. Proc. Linn. Soc. N.S. Wales, 23: 368.

Wood-Mason, J., 1875. On some new species of stomatopod Crustacea. Proc. Asiatic Soc. Bengal, $231-232$.

Wood-Mason, J., 1895. Figures and descriptions of nine species of Squillidae from the collection in the Indian Museum, Calcuta.: 1-11, 4. pls.

Zehntner, L., 1894. Crustaces de V Archipel Malais. Rev. Suisse Zool, 2: 212-213. 